\title{
Doris Lessing's Attitude to Marriage as Seen through the Albanian Binoculars
}

\section{Erinda Papa}

Lecturer at Fan S. Noli University, Korce, Albania

erindapapa@yahoo.com

\section{Benita Stavre}

Lecturer at Fan S. Noli University, Korce, Albania

b.stavre@gmail.com

\section{Doi:10.5901/mjss.2013.v4n10p520}

\begin{abstract}
Being considered a novelist of ideas, we believe Lessing's strength lies in her concept of the individual and his or her relation to the society. Because she deals with abstract ideas about women, men and society, and because she cannot place all her ideas in narrative context, her own voice comes through even more distinctly. She moves from realistic fiction to science fiction with a clearly didactic purpose: to make the individual alert of the risk that the unjust society poses to life itself. Therein lies her interest in marriage. This is going to be one of the main issues to be analyzed and compared to the Albanian environment. Martha Quest in "Children of Violence" series forces herself into marriage in an act of rebellion towards the tensions and the expectations of her traditional parents and community. Unlike Martha Quest the Albanian female is considered a curse from the very first moment she comes to light, due to the fact that she will provide no support to the family in the future (she is supposed to get married and join her husband's family), as compared to the male who is expected to provide all the commodities to the parents and the relatives. Therefore, the aim of this presentation is to show Lessing's attitude towards marriage as compared to the Albanian reality of the female identity defined by her relation to any man in her life.
\end{abstract}

While reading Doris Lessing's fiction, one can not go without noticing the insistence of the writer to overcome the limitations imposed by the patriarchal society before the individual. Under this view, the subject of marriage and its role in the loss of individual independence marks one of the most important problems covered by this prose writer. Her desire is to overcome social categories and restrictions imposed onto the individual especially the female one.

Marriage, a traditional social product, in Lessing's fiction is never described as a supporting category, or one that incites freedom to intimate relationships. The woman described in Lessing's work, whether divorced, married, single, or widowed, seeks independence from men, though often turns to her role as a wife, because ultimately she is dependent physically, emotionally and financially on men. ${ }^{1}$ Doris Lessing does not accept the feminist view that men are born to keep women oppressed, claiming that it is the society, not biology that determines the role of women and stifles initiative and talent. It seems as if the writer brings up some thought from Simon de Beauvoir's reflections when she proclaims that a woman is not born, but rather becomes one ${ }^{2}$. The impact of marriage on restrictions placed on individual female are especially apparent in the short story To Room Nineteen or in the novels The Grass Is Singing and The Summer Before the Dark.

In most of her prose writing, beginning with the earliest stories to her latest novels, Mrs. Lessing makes use of the issue of marriage to come up with the idea that marriage is a symbol of the individual's inability to find a coherent and balanced place in society, and that it marks a destructive, but necessary force to human life. Here it lays the connection with a male-dominated Albania, where married women still struggle to attain the freedom to choose their career after marriage, as society often considers them fit only for housekeeping and child rearing.

This is why D. Lessing focuses on the husband - wife relationships to highlight her views about the limitations imposed by society. In the short story To Room Nineteen, the writer unveils that when one fails to put reason in balance with feeling, it will generate the destruction of the relationship. This lack of balance in the Rawlings marriage brings failure of harmony in their relationship. Susan Rawlings feels imprisoned within the four walls of the house. The same picture is drawn even in the Alanian family, where the husband heads the family and makes all decisions on family

\footnotetext{
${ }^{1}$ Susan Watkins. (2010). Doris Lessing. Manchester and New York: Manchester University Press. p. 84.

${ }^{2}$ Simone de Beauvoir. (1989). The Second Sex. USA: Vintage Books Edition. p. vii.
} 
matters. Women must obey their husbands, do the housework, and look after the children. Couples usually live with the bridegroom's parents so they can care for them. Living in extended families also helps the couples to reduce expenses. Susan Rawlings' attempts to escape the conjugal prison lead her to Room Nineteen. She occupies this room as "someone", any person who in appearance resembles many other women who had previously rented the room. Under this view, the "any-person" symbolizes the same person in the same role Susan has long ago taken in her conjugal life. In both cases she is forced to adapt herself to the shape dictated by others or by her awareness. In her family, Susan is appreciated on the basis of relationships she establishes with her children, with her spouse, or as the housewife, the house caretaker. At the beginning, Susan feels emotionally free in Room Nineteen, but as the time flees she "realizes" that this place, away from the cave she took her name and form, is not the desired paradise, but her mental hell.

At the beginning of the story the narrator says, "This is a story, I suppose, about a failure in intelligence: the Rawlings' marriage was grounded in intelligence." ${ }^{3}$ At this point, the narrator makes it clear that whatever choice Susan makes, she will remain unbalanced, for she chose "either reason or feeling instead of balancing them in life". ${ }^{4}$ In presenting categories - reason / feeling; wife / mother / woman / caretaker - Mrs. Lessing stresses once again the idea that society itself is divided into such categories. It requires the individual to meet the specific role within the category. The inability of the individual to harmonize different functions within different categories leads to her mental or physical destruction. In this sense, the writer opposes marriage as a predetermined social category, because it forces women to undergo their role within the category by giving up emotion.

The anthropologist Antonia Young suggests in her very interesting study Women Who Become Men : Albanian Sworn Virgins, that "to be a woman is basically an occupational status, if seen socially ... to keep the household in a way that the male world runs smoothly without problems". ${ }^{5}$ The Kanun 6 is explicit about the purpose of women's lives: "A woman is known as a sack made to endure as long as she lives in her husband's house. Her parents do not interfere in her affairs, but they bear the responsibility for her and must answer for anything dishonorable that she does." Men's control of women is also outlined: 'the parents of his .. . wife .. . give him (the groom) a cartridge' as protection against 'two acts (for which) a woman may be shot in the back ... a) for adultery; b) for betrayal of hospitality' (to any guest). The preservation of this law continued to be demonstrated until quite recent times, the bridegroom's parents giving the groom a cartridge on the wedding day. ${ }^{8}$ Role-playing is central in understanding gender communication in Albania. Deprived of any social right the Albanian female existence is labeled in terms of male service. A very interesting point on role playing is made by Antonia Young in her study undertaken while observing life in the North of Albania. She listed according to Kanun ${ }^{9}$ a number of jobs performed by man including hard labour tasks (chopping the wood, harvesting and cropping or shepherding), paying the respects to the guests as well as maintaining and protecting the honor of the family. Meanwhile the woman was supposed to give birth to and raise children, take care of cooking and the households, serving to the men and the guests of the family (including the washing of their feet); carrying water and firewood, preparing dairy products, insurance and food storage, doing the laundry, sewing and embroidery as well as preparing the dowry. Moreover, they had to carry out all the works performed by men in the case of blood feud. This was apparently one of the reasons that had excluded women from feud and led little by little to the birth of the idea that "craftsmanship was women's work" and "the war, a real man work". ${ }^{10}$

Cases of marriage described in Lessing's fiction do not only present the relationships within a cople, but they also determine the type of the individual and the community where they live. According to Doris Lessing, the identity of a man is determined by the work that he does, and also by his position in the social and economic hierarchy. Compared to them, the role and place of women in society is determined by the nature of the relationship she establishes to men.

${ }^{3}$ Doris Lessing. (1980). Stories. New York: Vintage Books Edition. p. 177.

${ }^{4}$ Shirley Budhos. (1980). An Examination of the Theme of Enclosure with Emphasis on Marriage, in Selected Works by Doris Lessing. London: St. John's University. pp. 21 - 22.

${ }^{5}$ B. Backer. (1979). Behind the Stone Walls: Changing Household Organization among the Albanians of Kosovo. Oslo: PRIO publication S-8/79. p. 307.

${ }^{6}$ The Kanun is a set of traditional Albanian laws. The Kanun was primarily oral and only in the 20th century was it published in writing. There is only one Kanun since the ancient times commonly referred to the "Kanun of Leke".

${ }^{7}$ Article XXIX of the Kanun: Shtjefen Gjeçov. (1989). Kanuni i Leke Dukagjinit. Tirana: Albniform. p. 38.

$8 \mathrm{lbid}, \mathrm{p} .40$.

${ }^{9}$ The Kanun in (Albanian) is a set of traditional Christian Albanian laws. The Kanun was primarily oral and only in the 20th century was it published in writing.

10lan Whitaker. (July,1981). "A Sack for Carrying Things: The traditional role of women in Northern Albanian Society", Anthropological Quarterly, Vol. 54, No.3. p. 150. 
Marriage imprisons women in the family spinning wheel and makes her a hostage of the traditional models defined in part by the society and partly influenced by personality.

Within the house man is the backbone of economic support, and the woman is forced to give up her profession, her previous life even her own name. Albeit Susan Rawlings had a prosperous job, a very confortable house furnished at will, after getting married is forced to give up everything - her job, her house, her name. This portraying brings us in mind the position of the traditional Albanian woman who from the day of her marriage is no longer called by her own name. Her husband's name (in the possessive form) is used when speaking of her. "The bride is the energetic young addition to the workforce, potential bearer of future inheritors to the home and land. She is the only person who does not share in the celebrations following the wedding ceremony. She stands, eyes downcast while all the guests partake of the lavish quantities of food and drink." ${ }^{11}$ Rose Wilder Lane described the young Albanian bride of the North during the mid twentieth - century as the person who once arriving at her husband's house "takes a humble place in the corner, standing, her hands folded on her breast, her eyes downcast, and for three days and nights she is required to remain in that position, without lifting her eyes, without moving, and without eating or drinking. On the second day ... she goes about the household, obeying the commands of the elders, always standing until they tell her to sit, and for six months, not speaking unless they address her."12

Janet Reineck describes the situation more vividly:

"In a high mountain village it is the morning after a wedding. A rooster crows. It must be day, but still dark. And cold. December. Her eyes sting, her head aches from too little sleep, from the cold. She isn't groggy. She wakes into a chilling awareness of her new life, and her new name, 'Bride'. The awareness stings her, rushes her pulse. The awareness, the sting, will hit her, wrench her from sleep, day after day, for months, for years, gradually diminishing, becoming ritual, habit, as she molds herself to fit her new persona."13

When she goes to her new husband's home she is known as nuse (new bride) until another son marries. During the first month of marriage a new bride is expected to be dressed in her best clothing and be ready at any time for visitors coming to meet her to approve her as a worthy new addition to the household.

In her short story Doris Lessing makes use of the metaphor of the house and the room to determine the physical, emotional and social restrictions she is inclined to. The role of women in Lessing's fiction changes in accordance with the changing needs of the families. For this reason, women are unable to undertake actions or to exercise their power as "free women". Although Mrs. Lessing does not give men absolute power, it should be noted that the author stresses the fact that it is the society itself which fuels gender inequality. The Nobelist tries to amplify women's attempts to save themselves from woman's social models and especially the recurring pattern of "a propper marriage", based on the utopian desire of female freedom.

Martha Quest in the "Children of Violence" series forces herself into marriage in an act of rebellion towards the tensions and the expectations of her traditional parents and community. Unlike Martha Quest the Albanian female is considered a curse from the very first moment she comes to light, due to the fact that she will provide no support to the family in the future (she is supposed to get married and join her husband's family), as compared to the male who is expected to provide all the commodities to the parents and the relatives. Therefore the Albanian woman is likely to be submissive to the male dominion first in the family and then in the society. Historically she had got no name of her own, but is regarded as "someone's daughter, wife or mother" ${ }^{14}$. Accomplishing this role the Albanian woman is forced into marriage by her father and/or other male relatives of her family.

The aspirations for freedom lead Martha Quest to a completely conventional marriage, to divorce, child abandonment and later to a love which, in the eyes of Lessing's heroine, gets the value of a real marriage. In the long calvary of this journey, Martha learns that "true freedom can be achieved only by throwing away marriage and responsibility of a marital relationship." ${ }^{15}$ This idea is followed in the last novel of the series, "The four-gated city". In this

\footnotetext{
${ }^{11}$ Antonia Young. (2000). Women Who Become Men: Albanian Sworn Virgins. Oxford: Berg Publishers. p. 27.

12 R. W. Lane. (1922). The Peaks of Shala: Being a Record of Certain Wanderings among the Hill-Tribes of Albania. London: Chapman 6C Dodd; New York: Harper \&C Bros. p. 25.

13 J. Reineck. (1991). The Past as Refuge: Gender, Migration, and Ideology among the Kosova Albanians, Phd Thesis, University of California at BerKeley. p. 9.

14 Jason H. Tomes. (2003). King Zog of Albania: Europe's Self-Made Muslim King. New York University Press. p. 135.

15 Shirley Budhos. (1980). An Examination of the Theme of Enclosure with Emphasis on Marriage, in Selected Works by Doris Lessing, London: St. John's University. p.78.
} 
series of novels, the same difficulties are encountered by other characters who attempt to preserve traditional marriage, revealing once again the writer negative view about marriage.

In other literary works of Doris Lessing the reader can notice other choices made by her heroines in order to achieve freedom. Hence we can mention ménage a trois in A Man and Two Women), and adultery in Not a Very Nice Story. Elsewhere we can notice the choice to keep a relationship but without getting married. In all of these stories marriage is considered a prison and as one of the recurring patterns, but destructive to the individual's behavior. Referring to the Albanian case, A. Young states that it remains true that considerable sexual repression exists especially in traditional rural society. Sex is not discussed or even acknowledged amongst most women and extra-marital sex is theoretically non-existent, rare and severely punishable. Sex for women has always been seen to serve purely a procreative function. Birth control remains little known and undesired, large families are the norm, and the hope of always one more son is reason enough not to seek ways of preventing conception. ${ }^{16}$

Although this is a minor attempt to show some of the attitudes to marriage identified in Lessing's fiction and in Albanian reality at the time Doris Lessing puts the events in her prose works, we can notice how close and detached at the same time the two cases stand. What remains common to both situations is the fact that to Lessing marriage is seen as a traditional institution which imposes its beliefs onto the individual. During mid twentieth century the same attitude hold true even in Albania. Traditional Muslims and Orthodox Christians generally do not recognize dating as a prerequisite for marriage, although modern Albanian youth would disagree. In any event, families expect dating couples to follow a strict code of conduct in public places. Although Albanian youth make their own choice of spouse, they highly value their parents' approval. A formal engagement ceremony marks the proposal of marriage. In rural Albania, parents still arrange marriages with the help of a matchmaker. In fact, sometimes couples become betrothed even before they reach puberty. In northern Albania, men may pay a "bride price" for their future bride, and among certain tribes in the mountains, the tradition of the armed relatives of the bridegroom "stealing" the bride still commonly precedes a formal wedding. Traditionally, Albanians celebrate weddings for seven days. Premarital sex, once punishable, has now become a common indulgence in Albanian society, and the number of extramarital affairs has been rising over the last decade. Polygamy, however, remains generally prohibited in Albania. To sum it up, what Doris Lessing advices through her portraying of marriage as a negative influence in the individual's life, is that harmony and success depends on the possibility of a society which does not imposes its belief, and on the individual who is ready to put a balance between reason and feeling.

\section{References}

Backer, B. (1979). Behind the Stone Walls: Changing Household Organization among the Albanians of Kosovo. Oslo: PRIO publication S-8/79.

Beauvoir, Simone de. (1989). The Second Sex. USA: Vintage Books Edition.

Budhos, Shirley. (1980). An Examination of the Theme of Enclosure with Emphasis on Marriage, in Selected Works by Doris Lessing, London: St. John's University.

Gjeçov, Shtjefen. (1989). Kanuni i Leke Dukagjinit. Tirana: Albniform.

Lane, R. W. (1922). The Peaks of Shala: Being a Record of Certain Wanderings among the Hill-Tribes of Albania. London: Chapman 6C Dodd; New York: Harper \&C Bros.

Lessing, Doris. (1980). Stories. New York: Vintage Books Edition.

Reineck, J. (1991). The Past as Refuge: Gender, Migration, and Ideology among the Kosova Albanians, Phd Thesis, University of California at BerKeley.

Tomes, Jason H.. (2003). King Zog of Albania: Europe's Self-Made Muslim King. New York University Press.

Watkins, Susan. (2010). Doris Lessing. Manchester and New York: Manchester University Press.

Whitaker, Ian. (July, 1981). "A Sack for Carrying Things: The traditional role of women in Northern Albanian Society". Anthropological Quarterly. Vol. 54, No.3.

Young, Antonia. (2000). Women Who Become Men: Albanian Sworn Virgins. Oxford: Berg Publishers.

${ }^{16}$ Antonia Young. (2000). Women Who Become Men: Albanian Sworn Virgins. Oxford: Berg Publishers. p. 31. 